
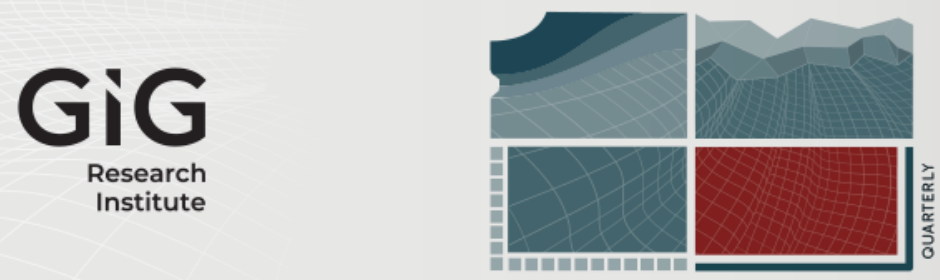

JOURNAL
OF
SUSTAINABLE
MINING

\title{
The identification of heavy metal accumulator ferns in abandoned mines in the Philippines with applications to mine rehabilitation and metal recovery
}

Author(s) ORCID Identifier:

Rene Juna R. Claveria (iD 0000-0001-9047-7547

Teresita R. Perez (D) 0000-0003-3018-3605

Ian A. Navarrete (iD) 0000-0001-6701-9951

Rubee Ellaine C. Perez (D) 0000-0002-8796-7884

Brian Christian C. Lim (D) 0000-0003-1664-1462

Follow this and additional works at: https://jsm.gig.eu/journal-of-sustainable-mining

Part of the Explosives Engineering Commons, Oil, Gas, and Energy Commons, and the Sustainability Commons

\section{Recommended Citation}

Claveria, Rene Juna R.; Perez, Teresita R.; Navarrete, Ian A.; Perez, Rubee Ellaine C.; and Lim, Brian Christian C. (2020) "The identification of heavy metal accumulator ferns in abandoned mines in the Philippines with applications to mine rehabilitation and metal recovery," Journal of Sustainable Mining: Vol. 19 : Iss. 1 , Article 6.

Available at: https://doi.org/10.46873/2300-3960.1005

This Research Article is brought to you for free and open access by Journal of Sustainable Mining. It has been accepted for inclusion in Journal of Sustainable Mining by an authorized editor of Journal of Sustainable Mining. 


\title{
The identification of heavy metal accumulator ferns in abandoned mines in the Philippines with applications to mine rehabilitation and metal recovery
}

\begin{abstract}
This paper focuses on the identification of some plant accumulators of heavy metals that can facilitate mine remediation and rehabilitation in the Philippines and metal recovery or phytomining. Most of these hyperaccumulators are ferns that thrive very well in different terrains and of particular interest are Pityrogramma calomelanos, Pteris vittata, and Pteris melanocaulon that are abundant in abandoned CueAu mining areas. The amounts of $\mathrm{Cu}$ and $\mathrm{As}$ in the soil and in the aboveground (AG) and belowground (BG) components of the accumulator ferns were determined and the Bioaccumulation Factor (BF) and the Translocation Factor (TF) were derived. Efforts to propagate the accumulator ferns identified from spores were successful, thus providing the opportunity of using them for various experiments on mine rehabilitation and metal recovery. The results of these experiments indicated that these hyperaccumulator ferns have the greatest potential for the remediation of metal contaminated soils, the rehabilitation of abandoned mines, and phytomining.
\end{abstract}

\section{Keywords}

Hyperaccumulator ferns; Mine rehabilitation; Phytoremediation; Phytomining

\section{Creative Commons License}

\section{(c) (i)}

This work is licensed under a Creative Commons Attribution 4.0 License.

\section{Authors}

Rene Juna R. Claveria, Teresita R. Perez, Ian A. Navarrete, Rubee Ellaine C. Perez, and Brian Christian C. $\operatorname{Lim}$ 


\title{
The identification of heavy metal accumulator ferns in abandoned mines in the Philippines with applications to mine rehabilitation and metal recovery
}

\author{
Rene Juna R. Claveria ${ }^{a, *}$, Teresita R. Perez ${ }^{a}$, Ian A. Navarrete ${ }^{a}$, \\ Rubee Ellaine C. Perez ${ }^{b}$, Brian Christian C. Lim ${ }^{a}$ \\ ${ }^{a}$ Department of Environmental Science, Ateneo de Manila University, Loyola Heights, Quezon City, Philippines \\ ${ }^{\mathrm{b}}$ National Institute of Molecular Biology and Biotechnology, University of the Philippines at Los Baños, Laguna, Philippines
}

\begin{abstract}
This paper focuses on the identification of some plant accumulators of heavy metals that can facilitate mine remediation and rehabilitation in the Philippines and metal recovery or phytomining. Most of these hyperaccumulators are ferns that thrive very well in different terrains and of particular interest are Pityrogramma calomelanos, Pteris vittata, and Pteris melanocaulon that are abundant in abandoned $\mathrm{Cu}-\mathrm{Au}$ mining areas. The amounts of $\mathrm{Cu}$ and As in the soil and in the aboveground (AG) and belowground (BG) components of the accumulator ferns were determined and the Bioaccumulation Factor (BF) and the Translocation Factor (TF) were derived. Efforts to propagate the accumulator ferns identified from spores were successful, thus providing the opportunity of using them for various experiments on mine rehabilitation and metal recovery. The results of these experiments indicated that these hyperaccumulator ferns have the greatest potential for the remediation of metal contaminated soils, the rehabilitation of abandoned mines, and phytomining.
\end{abstract}

Keywords: hyperaccumulator ferns, mine rehabilitation, phytoremediation, phytomining

\section{Introduction}

$\mathrm{M}$ ining associated with the exploitation of metals such as cobalt, chromium, copper, iron, and nickel has been a global industry throughout the centuries. In the Philippines, the mining industry has greatly contributed to the socio-economic development of the country since the 1600s. With the history of progressive mining in the Philippines, which started even before World War II, comes the inevitability of a slow down with the expected depletion of metal resources. There have already been some reports of abandoned mines in various provinces such as those in the Cordillera and Mindanao and Bicol regions. Despite monetary gains, mining activities remain controversial due to their highly extractive nature. Mining sites tend to become contaminated areas of various metals, some of which could be toxic. The mined-out areas are left unviable for any use, because they are nutrientdeficient and erosion-prone with little to no vegetation. Current clean-up technologies via physical and chemical remediation methods remain expensive, especially for developing countries. The search for Green Technologies in mining has been a challenge, particularly within the perspective of what Responsible Mining is. It is inevitable that the apparent natural state of an ecosystem is disturbed during the various stages of mine development. Appreciating the ecological structure of an area could provide answers; one of which is the identification of an indigenous plant species that can be used for remediation and

Received 21 May 2019; revised 13 December 2019; accepted 10 February 2020.

Available online 5 October 2020

* Corresponding author.

E-mail address: rclaveria@ateneo.edu (R.J.R. Claveria). 
rehabilitation. Studies in phytoremediation have on various occasions provided opportunities to discover new plant species that can accumulate metals into their biological tissues. Interestingly, these plant species thrive in specific metalliferous terrains and are not commonly observed to occur elsewhere.

Understanding the accumulation potential of these plants is of great importance and from this understanding a certain plant species could be characterized and identified as a hyperaccumulator. A hyperaccumulator is $100 x$ more capable of absorbing metals into its system than the metal content in the soil [1]. Hyperaccumulators are normally used in studies related to metal recoveries with the underlying concept of removing metals from contaminated soils with the use of the natural or induced metal tolerance and accumulation capacities of some plant species. The recovery of metals from contaminated soils and water is the goal of phytoremediation [2,3]. The use of plants to extract metals directly from the soil is called phytoextraction, which is the basis of the concept of phytomining, where plants are harvested and the metal contents extracted and sold. The utilization of hyperaccumulators will not only be beneficial for mine restoration, but also for the livelihood of communities around the mining area.

The Philippines is a mega-center for biodiversity and the challenge faced here is the identification of plants capable of copper $(\mathrm{Cu})$ and arsenic (As) hyperaccumulation. These plant hyperaccumulators can be used in the rehabilitation of abandoned mining areas and consequently in the value adding (phyto) extraction of metals. This initiative is an important step in the ecological restoration of a previously mined area and could eventually lead to various stages of habitat successions [4]. Ferns are of particular interest because of their high adaptability to different kinds of terrains and to extreme environmental limiting factors. There are very few studies about ferns in the Philippines, and especially those of the Pteridaceae family which are known to be drawn towards hyperaccumulation. This study seeks to determine the metal accumulation capabilities of ferns. The information gathered could lead to the identification of hyperaccumulator ferns that are suitable for mass cultivation, phytoremediation and phytomining. They can provide additional economic benefits while remediating the soil for future agricultural use [5].

The objectives of this study were a) to identify the presence of indigenous ferns (as metallophytes and hyperaccumulators) found in selected study areas through field surveys, b) to determine the uptake capability of the selected ferns, and c) to recover $\mathrm{Cu}$ from the identified hyperaccumulators through metallurgical/chemical processes. The significance of the study is the feasibility of on-field applications of hyperaccumulator ferns in post-mining rehabilitation and the innovation of extracting $\mathrm{Cu}$ from a $\mathrm{Cu}$ accumulator and in turn the feasibility of phytomining in general. These applications were put forward to achieve certain benefits from what supposedly are useless contaminated areas such as abandoned mines. In order to appreciate the uptake and heavy metal accumulation of the identified indigenous ferns and consequently metal recovery, discussions on the different possible uptake mechanisms of the plant species are provided based on previous studies that were made on the selected ferns.

\section{Materials and methods}

Field surveys were conducted in some of the metal-rich areas in the Philippines covering the islands of Luzon, Visayas and Mindanao (Fig. 1). These areas were previously open pit mines and mine tailing dump sites which are likely to be enriched with heavy metals. It is of interest to identify plants that can accumulate heavy metals from the soil, and specifically to know how much of the available metals are being taken up by these plants. The selection of specific plants, particularly ferns, was based on a) their occurrence, being more abundant than other plant species, b) their presence, being the first and only plants that grow and thrive in the area and c) their tolerance, being able to grow in soils notably enriched or contaminated with heavy metals. The field surveys have evaluated the natural environment of the areas where the plants grow and propagate. Metallophytes were known to thrive in nickeliferous lateritic terrains. The 2 nickeliferous laterite deposits considered in this study were in the provinces of Zambales (Acoje) and Palawan (Brookes Point). In general, the 2 deposits are underlain by ultramafic rocks as part of some ophiolitic complexes [6,7]. The in-situ weathering of these ultramafic rocks has produced nickeliferous laterite profiles with varying thicknesses of the limonite and saphrolite horizons [8]. Laterite development was noted to thicken in plateau areas with approximately $500-1000 \mathrm{~m}$ elevations. As part of the limonite zone, the red to dark red near surface soils are enriched with iron oxides. Metallophytes and hyperaccumulators were also identified as growing abundantly in abandoned $\mathrm{Cu}-\mathrm{Au}$ mines as well as in small scale mining areas such as those in 


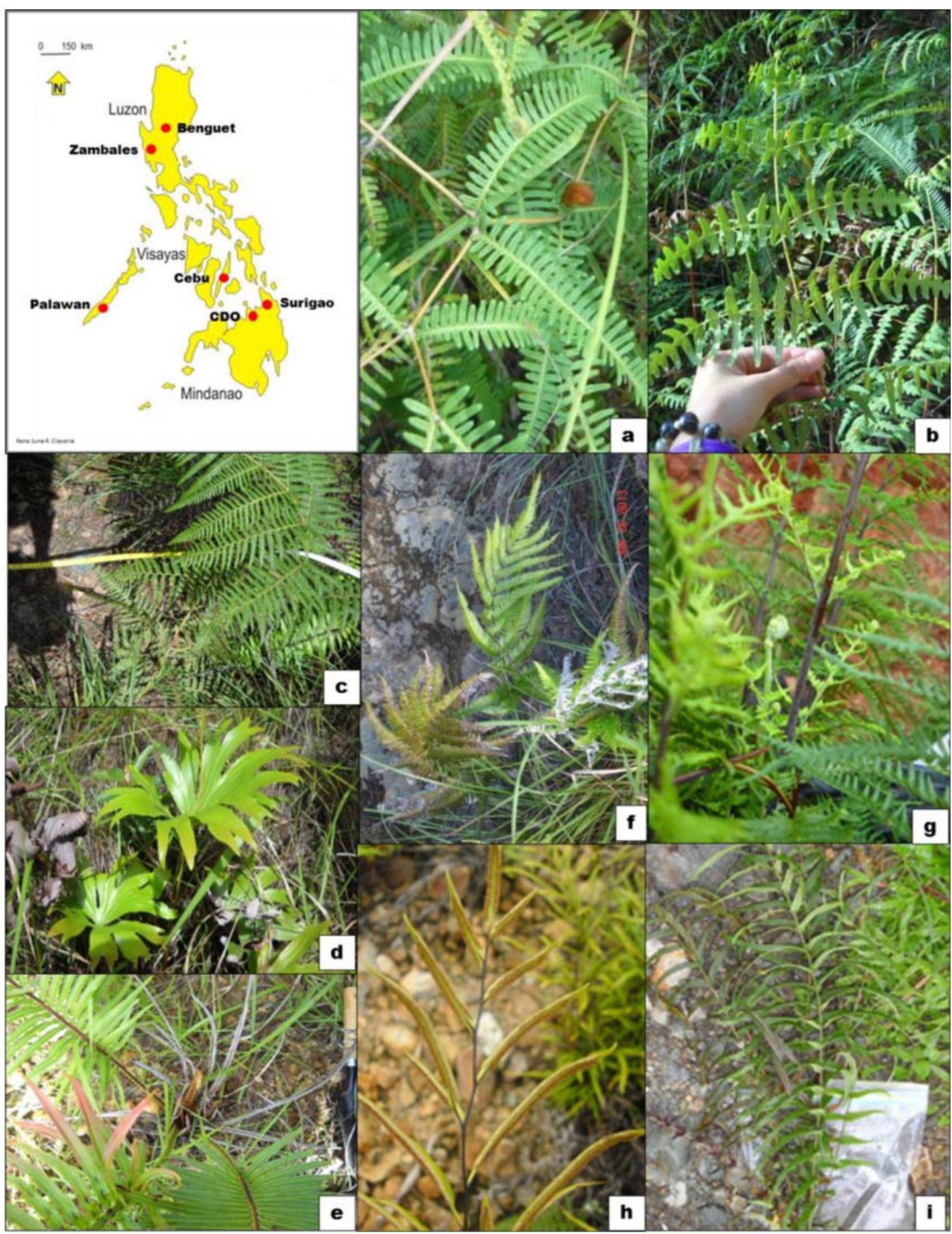

Fig. 1. Photographs of the common ferns found abundant in some Fe-Ni mines as well as $C u-A u$ mines in the Philippines. a) D. linearis, b) $H$. incisa, c) Pteridium sp., d) D. conjugate, e) B. orientale, f) Pteris sp., g) P. calomelanos, h) P. melanocaulon, i) P. vittata. Inset is a map of the Philippines showing the different sampling sites.

the provinces of Benguet, Cebu, and Surigao. In general, the $\mathrm{Cu}-\mathrm{Au}$ mines in the 3 provinces are hydrothermal $\mathrm{Cu}-\mathrm{Au}$ deposits occurring as $\mathrm{Cu}-\mathrm{Au}$ porphyries and epithermal deposits [9]. The extraction processes are by open pit and underground mining and in some areas small scale or artisanal mining is being performed. The soils that are developed in these areas are products of the weathering of hydrothermally altered rocks which are significantly enriched with heavy metals. Soil 
development in these areas is also related to the weathering of old tailing ponds which are also enriched with heavy metals. It is also noted that these areas receive sufficient precipitation throughout the year making them conducive for plant growth. It was of interest to know how much heavy metals the plants and particularly the ferns could accumulate in their anatomical structures in consideration of the below and above ground components.

Plant and soil samples were collected. The plant samples gathered consisted of ferns. In total, about 14 different fern species were identified in the nickeliferous laterite and hydrothermal $\mathrm{Cu}-\mathrm{Au}$ deposits. The entire fern with fronds and roots is taken as a sample. The aboveground (stem and leaves) and belowground (roots) components of the plants were taken with considerable care to avoid breakage of the different parts. In the selected sampling sites, the occurrences of the ferns vary. There are areas where a number of different ferns thrive together with some ferns being more abundant than others and there are also some areas where only 1 to 2 types of fern thrive either in abundance or are few in number. In areas where there is a relative abundance of specific ferns, triplicate sampling was performed and in areas where relatively few ferns occur, composite sampling was considered. The presence and relative abundance of the ferns in the selected study areas are significant indicators of the ability of the ferns to thrive in areas enriched with heavy metals. The corresponding soils where the plants have grown were taken with significant consideration of the depth to which the root system of the plant has extended. Similarly, composite soil samples of mixed rhizosphere and non-rhizosphere were taken in some areas where few fern species thrive. The collected plants were submitted for identification at the Institute of Biology, the University of the Philippines (Diliman) and the Philippine National Herbarium. The different plant species were identified accordingly. After following proper protocols, such as those of the Association of Analytical Chemists (AOAC) on sample preparation, the plant and soil samples were analyzed for metal and metalloid contents $[10,11]$.

In the sample preparation of the plant samples, prior to chemical analyses, the samples were washed with tap water to remove any soil and dust that could be attached in the stem, leaf and root components of the plant and which may contain metals and metalloids. After washing, the plants were rinsed with deionized water and were oven dried to about $60-70^{\circ} \mathrm{C}$ [11]. In order to know the elemental concentrations in the different parts of the plant, the fern samples were separated into root/ rhizome, stipe, and lamina components. Some of the composite samples were prepared as whole plant samples and were not separated into above and belowground components. Such preparation was carried out in order to provide the study with an initial impression of the bioaccumulation factor of the ferns. During the preparation for analysis, the plant samples were acid digested with concentrated nitric acid [12]. The soil samples were air dried. When determining the element concentrations of the soil, the samples were prepared by acid digestion using concentrated nitric acid [12]. The elemental contents of the plant (whole plant, aboveground and belowground components) and soil samples were analyzed using the Avanta GBC Atomic Absorption Spectrophotometer utilizing various lamps. The metals analyzed included $\mathrm{Cr}$, $\mathrm{Co}, \mathrm{Cu}, \mathrm{Fe}$, and $\mathrm{Ni}$. For As measurements an atomic absorption spectrophotometry with hydride generation (HG-AAS) analysis was used. The standard solutions were prepared with distilled water $[12,13,14]$. With the determined element concentrations in the plant and soil samples, the Bioaccumulation Factor (BF) and the Translocation Factor (TF) were calculated using the ratio between plant and soil $(\mathrm{BF}=$ Plant/Soil) and the ratio between aboveground and belowground components $(\mathrm{TF}=$ aboveground $\quad(\mathrm{AG}) /$ belowground $\quad(\mathrm{BG}))$ $[11,15]$.

In the post-mining rehabilitation experiments, the selected sites of the plots at Kias (Benguet) took into consideration the development of at least a few centimeters of soil cover found above the tailings. The presence of a soil cover above mine tailings was needed as ground preparation to enable the plants initial growth and survival. Such preparation included the use of uncontaminated soils taken within the vicinities of the mine tailings and the addition of soil amendments for plant growth. Two experimental plots with dimensions of approximately $3 \mathrm{~m}$ in length and approximately $1 \mathrm{~m}$ in width were prepared. In Surigao, the selected site for rehabilitation was Suyoc North which was formerly an open pit $\mathrm{Cu}$ mine. The area is about $1 / 4$ hectares of relatively flat terrain with no vegetation. The soil cover is either relatively thin or non-existent. Ground preparation was done specifically in areas where the ferns were to be planted. The preparations included the use of uncontaminated soils with soil amendments, some of which were used during the early propagation of the ferns in nurseries.

In the phytoextraction experiments, the hyperaccumulator ferns that exhibit efficient uptake of 
metals/metalloids, with the aboveground components having higher values than the belowground components, thus a TF ratio that is $>1$, were candidates for the possible extraction of metals/metalloids directly from the plant. The higher TF values manifest the unique ability of the ferns to store heavy metals in the fronds and are not affected by phytotoxicity [1]. These are exemplified by hyperaccumulator ferns such as Pityrogramma calomelanos, Pteris vittata and Pteris melanocaulon. [16] indicated that the BG components of $P$. melanocaulon were relatively high in $\mathrm{Cu}$ with average values of about $4590 \pm 386 \mathrm{mg} \mathrm{kg}^{-1}$. In the same study, the authors indicated that the uptake of $\mathrm{Cu}$ by the fern in the roots was partly due to the high amounts of $\mathrm{Cu}$ in the soils in the mine area which had an average of about $1137.56 \pm 297.48 \mathrm{mg} \mathrm{kg}^{-1}$ and that it was higher than the crustal average of $\mathrm{Cu}$ which is $58 \mathrm{mg} \mathrm{kg}^{-1}$. The high content of $\mathrm{Cu}$ in the soils would have a major influence on the uptake of higher amounts of $\mathrm{Cu}$ by the plant [15]. From this information an experimental study on extracting metals from roots was performed using $P$. melanocaulon. Plant samples of $P$. melanocaulon were collected in an abandoned $\mathrm{Cu}-\mathrm{Au}$ mine in Surigao where, apparently, the ferns thrive abundantly. The extraction process taken into consideration was electrowinning with the goal of separating $\mathrm{Cu}$ (as cations) from a solution that was laden with $\mathrm{Cu}$ and came from the dissolution of the root component of $P$. melanocaulon. The study placed emphasis on the extraction of $\mathrm{Cu}$ in the solution and did not considered the recovery of other metals which could be associated with $\mathrm{Cu}$, such as As. In the experiment, the variable parameters analyzed included the digesting solutions which were nitric acid and aqua regia. The preparation of the solutions followed the protocols provided by [17]. The other variable parameters were voltage $(1.5,3$ and $6 \mathrm{~V})$ and time (30,60 and $90 \mathrm{~min})$. Changes in $\mathrm{pH}$ and temperature which may have an effect on metal recovery [18] were also taken into consideration. In addition, the types of electrodes used as well as the amount of agitation applied in the experiment were considered. Agitation allows metal ions to circulate in the solution and may assist in the deposition of the metals onto the cathodes [19]. Electrowinning setups with aluminum electrodes were made for each solution with 3 setups manifesting the tests on 3 different voltages and for each voltage the tests are on 3 different time frames. Atomic Absorption Spectrophotometry (AAS) was used to analyze the $\mathrm{Cu}$ concentration before and after electrowinning. The goal of the experiment was to determine the most efficient combination (solution, voltage and time) in extracting the highest $\%$ of $\mathrm{Cu}$ and thus the highest $\%$ of metal recovery. The limiting factor in the extraction process is the concentration of the metal in a solution which at high concentrations, the recovery of the metal would be high as well.

\section{Results and discussions}

\subsection{Field surveys}

\subsubsection{Accumulator ferns in nickeliferous laterite mines}

The analyses of the lateritic soils from the study sites confirmed the relatively high concentrations of $\mathrm{Fe}$ and $\mathrm{Ni}$ (Table 1). In the study sites, 3 metal tolerant ferns were found to thrive very well; these being Pteridium aquilinum and Sphenomeris retusa in the Zambales area and Dicranopteris linearis in Palawan. In all 3 fern samples, the amount of $\mathrm{Fe}$ absorbed by the plants was relatively high, at about $11492.98 \mathrm{mg} \mathrm{kg}^{-1}$ for $P$. aguilinum, $4419.89 \mathrm{mg} \mathrm{kg}^{-1}$ for $S$. retusa and about $3043.62 \mathrm{mg} \mathrm{kg}^{-1}$ for D. linearis, as compared to other metals such as $\mathrm{Ni}$ where the values range from 7.79 to about $107.09 \mathrm{mg} \mathrm{kg}^{-1}$. This was expected because of the very high concentrations of $\mathrm{Fe}$ in the soil which were approximately $52061.41 \pm 40836.92 \mathrm{mg} \mathrm{kg}^{-1}$ on average in the Zambales (Acoje) study site to a high of $102803.8 \mathrm{mg} \mathrm{kg}^{-1}$ in the Palawan (Brookes Point) study site. The consequential increase of Fe in plants due to the Fe increase in soil classifies them as indicator ferns for Fe.

The BF values of the different metals (e.g. Co, $\mathrm{Cr}$ and $\mathrm{Ni}$ ) among the 3 fern species were $<1.0$, which indicates relatively the inefficient uptake potential of the plants. This property may indicate the exclusionary mechanism of the plants to absorb just enough metals to avoid phytotoxicity, which is also the tolerant characteristics of other metallophytes to thrive well in soils with high metal contents [20]. The $\mathrm{Cr}$ TF values between the 3 ferns, however, were about $\geq 1.0$ which shows the efficient transfer of $\mathrm{Cr}$ from roots to fronds. Such distribution is indicative of the capability of the ferns to tolerate absorbed $\mathrm{Cr}$. These observations are of significant interest and it is highly recommended that further studies be made to confirm the $\mathrm{Cr}$ hyperaccumulation potentials for the plants.

\subsubsection{Accumulator ferns in $\mathrm{Cu}-\mathrm{Au}$ mines}

The $\mathrm{Cu}-\mathrm{Au}$ mines used as study sites were: a) the Lepanto Mine (in Mankayan, Benguet), b) the Acupan Mine (in Itogon, Benguet), c) Camp 6 (in Tuba, Benguet), d) the Philex Mine (in Tuba, Benguet), e) the Carmen Mine (in Toledo, Cebu), f) Manila Mining (in Placer, Surigao), g) the Silangan Mine (in 
Table 1. $\mathrm{Cu}$ and As content of different fern species taken from nickeliferous laterite and $\mathrm{Cu}-\mathrm{Au}$ mines in different localities in the Philippines. Indicated are the elemental contents of the soil as well as the belowground (BG) and aboveground (AG) components of the plant. Based on the elemental contents of the soil as well as the BG and AG of the plant, the bioaccumulation factor (BF) and the translocation factor (TF) were computed. Highlighted values are $>1.00$. The samples with computed averages are samples taken as triplicates and those without computed averages are samples taken as composite.

\begin{tabular}{|c|c|c|c|c|c|c|c|}
\hline Site & 1Plant & Element & Soil $\left(\mathrm{mg} \mathrm{kg}^{-1}\right)$ & $\mathrm{BG}\left(\mathrm{mg} \mathrm{kg}^{-1}\right)$ & $\mathrm{AG}\left(\mathrm{mg} \mathrm{kg}^{-1}\right)$ & $\mathrm{BF}$ & $\mathrm{TF}$ \\
\hline Acoje & Pteridium Aquilinum & Co & $410.77 \pm 24.25$ & 63.04 & & 0.15 & \\
\hline Zambales & & $\mathrm{Cr}$ & $642.81 \pm 258.62$ & 62.45 & 95.62 & 0.25 & 1.53 \\
\hline Luzon (Nickeliferous & & $\mathrm{Fe}$ & $52061.41 \pm 40836.98$ & 9358.29 & 2134.69 & 0.22 & 0.23 \\
\hline \multirow[t]{5}{*}{ Laterite Mine) } & & $\mathrm{Ni}$ & $2904.13 \pm 317.73$ & 97.44 & 9.57 & 0.04 & 0.10 \\
\hline & Sphenomeris retusa & Co & $410.77 \pm 24.25$ & 19.61 & & 0.05 & \\
\hline & & $\mathrm{Cr}$ & $642.81 \pm 258.62$ & 47.70 & 45.49 & 0.14 & 0.95 \\
\hline & & $\mathrm{Fe}$ & $52061.41 \pm 40836.98$ & 3861.94 & 557.95 & 0.08 & 0.14 \\
\hline & & $\mathrm{Ni}$ & $2904.13 \pm 317.73$ & 36.16 & & 0.01 & \\
\hline Brookes Point Palawan & Dicranopteris linearis & $\mathrm{Cr}$ & 249.83 & 34.77 & 37.64 & 0.29 & 1.08 \\
\hline Luzon (Nickeliferous & & $\mathrm{Fe}$ & 102803.8 & 2974.80 & 68.82 & 0.03 & 0.02 \\
\hline Laterite Mine) & & $\mathrm{Ni}$ & 4610.67 & 7.79 & & 0.001 & \\
\hline Camp 6 & Pteris vittata & $\mathrm{Cu}$ & 55.30 & 317.00 & 82.40 & 7.22 & 0.26 \\
\hline Benguet & & As & 13.70 & 53.70 & 175.00 & 16.69 & 3.26 \\
\hline Luzon $(\mathrm{Cu}-\mathrm{Au}$ Small & Pityrogramma & $\mathrm{Cu}$ & 55.30 & 816.00 & 51.70 & 15.69 & 0.06 \\
\hline Scale Mine) & calomelanos & As & 13.70 & 15.50 & 106.00 & 8.87 & 6.84 \\
\hline Philex Mines & Dipteris conjugata & $\mathrm{Cu}$ & 56.30 & 23.00 & 6.70 & 0.53 & 0.29 \\
\hline Benguet & Pteridium sp. & $\mathrm{Cu}$ & 31.50 & 4.65 & 3.99 & 0.27 & 0.86 \\
\hline Luzon (Cu-Au Mine) & Blechnum orientale & $\mathrm{Cu}$ & 73.80 & 10.80 & 10.50 & 0.29 & 0.97 \\
\hline Lepanto Mines & Nephrolepis hirsutula & $\mathrm{Cu}$ & 697.23 & 76.52 & & 0.11 & \\
\hline Benguet & & As & 1711.55 & 2.47 & & 0.001 & \\
\hline \multirow[t]{10}{*}{ Luzon (Cu-Au Mine) } & Dicranopteris linearis & $\mathrm{Cu}$ & 670.28 & 31.25 & & 0.05 & \\
\hline & & As & 27.59 & 7.19 & & 0.26 & \\
\hline & Histiopteris incisa & $\mathrm{Cu}$ & 697.23 & 151.66 & & 0.22 & \\
\hline & & As & 1711.55 & 2.47 & & 0.00 & \\
\hline & Pteris sp. & $\mathrm{Cu}$ & $1766.66 \pm 32.14$ & $2093.33 \pm 97.12$ & $17.00 \pm 0.00$ & 1.19 & 0.01 \\
\hline & & As & $1243.33 \pm 132.03$ & $179.33 \pm 11.37$ & $450.66 \pm 20.55$ & 0.51 & 2.51 \\
\hline & Pityrogramma & $\mathrm{Cu}$ & $1265.66 \pm 16.80$ & $229.66 \pm 11.84$ & $41.00 \pm 2.65$ & 0.21 & 0.18 \\
\hline & calomelanos & As & $2072.66 \pm 105.11$ & $473.33 \pm 7.02$ & $1227.33 \pm 30.56$ & 0.82 & 2.59 \\
\hline & Pteris vittata & $\mathrm{Cu}$ & $351.00 \pm 1.00$ & $89.00 \pm 7.21$ & $17.60 \pm 0.57$ & 0.30 & 0.20 \\
\hline & & As & $645.00 \pm 32.45$ & $246.33 \pm 8.32$ & $722.33 \pm 150.99$ & 1.50 & 2.93 \\
\hline Acupan & Pteris vittata & $\mathrm{Cu}$ & $106.33 \pm 2.00$ & $51.06 \pm 0.50$ & $9.92 \pm 0.26$ & 0.57 & 0.19 \\
\hline Benguet & & As & $25.80 \pm 1.61$ & $4.08 \pm 0.07$ & $80.10 \pm 2.71$ & 3.26 & 19.63 \\
\hline Luzon $(\mathrm{Cu}-\mathrm{Au}$ Small & Pityrogramma & $\mathrm{Cu}$ & $337.66 \pm 2.30$ & $404.66 \pm 6.50$ & $30.43 \pm 0.21$ & 1.29 & 0.08 \\
\hline Scale Mine) & calomelanos & As & $33.83 \pm 1.40$ & $12.66 \pm 0.31$ & $113.00 \pm 5.29$ & 3.71 & 8.93 \\
\hline Carmen Mine & Pityrogramma & $\mathrm{Cu}$ & $494.67 \pm 1.15$ & $1407.00 \pm 0.00$ & $117.33 \pm 1.53$ & 3.08 & 0.08 \\
\hline Cebu & calomelanos & As & $4.01 \pm 0.13$ & $5.16 \pm 0.09$ & $86.90 \pm 4.98$ & 22.96 & 16.84 \\
\hline \multirow[t]{4}{*}{ Visayas (Cu Mine) } & Pteris melanocaulon & $\mathrm{Cu}$ & $1538.33 \pm 6.66$ & $4623.33 \pm 77.16$ & $252.00 \pm 0.00$ & 3.17 & 0.05 \\
\hline & & As & $4.88 \pm 0.30$ & $1.83 \pm 0.12$ & $5.96 \pm 0.31$ & 1.60 & 3.26 \\
\hline & Blechnum orientale & $\mathrm{Cu}$ & $255.33 \pm 2.51$ & $635.33 \pm 0.58$ & $82.17 \pm 0.86$ & 2.81 & 0.13 \\
\hline & & As & $3.68 \pm 0.14$ & $0.80 \pm 0.07$ & $0.30 \pm 0.05$ & 0.30 & 0.38 \\
\hline Silangan Mine & Dicranopteris linearis & $\mathrm{Cu}$ & 151.80 & 49.30 & 5.00 & 0.36 & 0.10 \\
\hline Surigao & & As & 126.70 & 13.20 & 2.80 & 0.13 & 0.21 \\
\hline Mindanao $(\mathrm{Cu}-\mathrm{Au}$ & Blechnum orientale & $\mathrm{Cu}$ & 100.30 & 46.30 & 6.70 & 0.53 & 0.14 \\
\hline \multirow[t]{3}{*}{ Mine) } & & As & 131.50 & 21.20 & 0.50 & 0.17 & 0.02 \\
\hline & Cyathea sp. (fern & $\mathrm{Cu}$ & 129.80 & 60.90 & 5.50 & 0.51 & 0.09 \\
\hline & tree) & As & 161.10 & 4.10 & 2.50 & 0.04 & 0.61 \\
\hline Tompagon & Sphaerostephanos sp. & $\mathrm{Cu}$ & 44.60 & 43.80 & 5.90 & 1.11 & 0.13 \\
\hline $\begin{array}{l}\text { Misamis Oriental } \\
\text { Mindanao (Au Small } \\
\text { Scale Mine) }\end{array}$ & & & & & & & \\
\hline Manila Mining & Nephrolepis hirsutula & $\mathrm{Cu}$ & 181.50 & 86.20 & 12.20 & 0.54 & 0.14 \\
\hline Surigao & & As & 35.70 & 1.30 & 0.40 & 0.05 & 0.31 \\
\hline Mindanao $(\mathrm{Cu}-\mathrm{Au}$ & Pteris vittata & $\mathrm{Cu}$ & $134.00 \pm 5.29$ & $53.33 \pm 3.21$ & $8.13 \pm 0.11$ & 0.46 & 0.15 \\
\hline \multirow[t]{5}{*}{ Mine) } & & As & $64.66 \pm 4.51$ & $61.33 \pm 3.78$ & $388.00 \pm 9.54$ & 6.95 & 6.33 \\
\hline & Pityrogramma & $\mathrm{Cu}$ & $134.00 \pm 5.29$ & $1136.66 \pm 35.11$ & $12.00 \pm 0.00$ & 8.57 & 0.01 \\
\hline & calomelanos & As & $64.66 \pm 4.51$ & $14.00 \pm 0.00$ & $244.66 \pm 21.73$ & 4.00 & 17.48 \\
\hline & Pteris melanocaulon & $\mathrm{Cu}$ & $184.33 \pm 15.17$ & $2190.00 \pm 553.26$ & $114.66 \pm 42.01$ & 12.50 & 0.05 \\
\hline & & As & $16.66 \pm 1.15$ & $8.56 \pm 3.23$ & $20.00 \pm 17.32$ & 1.71 & 2.34 \\
\hline
\end{tabular}


Silangan, Surigao) and h) Tompagon (in Cagayan de Oro, Misamis Oriental). Various kinds of accumulator ferns were observed to thrive very well in a number of $\mathrm{Cu}-\mathrm{Au}$ mines, these being: a) Nephrolepis hirsutula (Lepanto Mine and Manila Mining), b) Pteris sp. (Lepanto Mine), c) Dicranopteris linearis (Lepanto Mine and Silangan Mine), d) Histiopteris incisa (Lepanto Mine and Philex Mine), e) Dipteris conjugata (Philex Mine), f) Pteridium sp. (Philex Mine), g) Blechnum orientale (Philex Mine, Carmen Mine and Silangan Mine), h) Cyathea sp. (Silangan Mine), i) Sphaerostephanos sp. (Tumpagon), j) Pityrogramma calomelanos (Lepanto mine, Acupan, Camp 6, Carmen Mine and Manila Mining), k) Pteris vittata (Lepanto Mine, Acupan, Camp 6, Carmen Mine and Manila Mining) and 1) Pteris melanocaulon (Carmen Mine and Manila Mining).

The results of analyses on the concentrations of $\mathrm{Cu}$ and As in the soils as well as the aboveground (shoots) and belowground (roots) components of the plants are shown in Table 1. It is noted that most of the ferns have $\mathrm{BF}$ values of $<1.0$ indicating that these plants do not possess mechanisms for $\mathrm{Cu}$ and As absorption in any of their anatomical structures. It also shows that these ferns are tolerant to higher amounts of $\mathrm{Cu}$ and As in the soils that they thrive in. Instead of absorbing $\mathrm{Cu}$ and As into their system, they have the mechanism of excluding metals/metalloids in their uptake of micronutrients for plant growth [21].

There are, however, ferns that have BF values of $>$ 1.0 indicating that the elemental concentrations in the plant are higher than that of the soil they thrive in. These ferns, which are commonly found in most of the study sites, are $P$. vittata, $P$. calomenlanos and $P$. melanocaulon. The range of $\mathrm{Cu} B F$ values of each species varies from: a) $P$. vittata $(0.33-7.22)$; b) $P$. calomelanos (0.21-15.69) and c) $P$. melanocaulon (3.17-12.50). Other ferns that exhibited $\mathrm{Cu} B F$ values of $>1.0$ are Pteris sp. (1.19), B. orientale (2.81) and Sphaerostephanos sp. (1.11). The range of As BF values also varies: a) $P$. vittata $(1.50-16.69)$; b) $P$. calomelanos $(0.82-22.96)$ and c) $P$. melanocaulon (1.60-1.71). With BF values of $\mathrm{Cu}$ and $\mathrm{As}>1.0$ these are classified as phytostabilizers of $\mathrm{Cu}$ and $\mathrm{As}$ and this capability enables them to thrive well in $\mathrm{Cu}$ and As enriched soils as metallophytes [16,22]. Studies have shown that $P$. calomelanos, which is a hyperaccumulator of $\mathrm{As}, \mathrm{Cd}$, and $\mathrm{Zn}$, is a likely contender for $\mathrm{Cu}$ phytostabilization because of the dominant $\mathrm{Cu}$ accumulation in the roots and rhizome and hardly any translocation in the shoots [23].

There are ferns that exhibited TF values that are $>$ 1.0. These ferns have the capability of transporting metals/metalloids from the roots to the shoots (stem and leaves). It is interesting to observe that there were no ferns from those identified that thrive in $\mathrm{Cu}$ and As enriched soils that exhibited $\mathrm{Cu}$ TF values of $>1.0$. This illustrates that ferns had mechanisms that minimize the movement of $\mathrm{Cu}$ into the stem and leaves to avoid possible toxicity, if the uptake were in excess of what is needed for plant growth [24]. The phytotoxicity of $\mathrm{Cu}$ might have been reduced due to the presence of As, which some ferns tend to accumulate as part of their biological adaptation to $\mathrm{Cu}-\mathrm{As}$ enriched soils [25]. The ferns with As TF values of $>1.0$ are $P$. vittata (2.93-19.63); P. calomelanos (2.59-17.48) and P. melanocaulon (2.34-3.26). Another fern that has a high As TF value is Pteris sp (2.51). The capability of these ferns to transport As from the roots to the stem and leaves without experiencing possible phytotoxicity characterizes them as excellent extractors and therefore hyperaccumulators [26-28].

From the 2 different study sites, nickeliferous laterite and $\mathrm{Cu}-\mathrm{Au}$ mines, specific ferns were identified and noted to thrive very well. These ferns are not only tolerant to the heavy metal enriched environments where they grow, but are also capable of accumulating considerable amounts of heavy metals into their anatomical systems, particularly the roots and fronds. In the nickeliferous laterite mines, $P$. aguilinun, $S$. retusa and $D$. linearis are the most dominant ferns as they are tolerant of, though not accumulators of, $\mathrm{Fe}, \mathrm{Co}$ and $\mathrm{Ni}$ with $\mathrm{BF}$ values of $<1.00$. However, initial observations from this study indicate that they could possibly be accumulators of $\mathrm{Cr}$ (TF values $>1.00$ ), though this requires further studies and confirmation. The occurrence of these ferns is relatively low to non-existent in the $\mathrm{Cu}-\mathrm{Au}$ mines. The ferns that are prominent in these areas are: $P$. calomelanos, $P$. vittata, $P$. melanocaulon, B. orientale, $N$. hirsutula, $H$. incisa, D. conjugate, Pteris sp. and Cyatea sp. Some of these ferns, such as $P$. calomelanos, $P$. vittata and $P$. melanocaulon, are identified as $\mathrm{Cu}$ and As hyperaccumulatros with $\mathrm{TF}$ values of $>1.00$ confirming previous studies on the ferns as $\mathrm{Cu}$ and As accumulators [15,16,29]. The other ferns appear tolerant to high amounts of $\mathrm{Cu}$ and As in the soils.

\subsection{Post-mining rehabilitation}

The concept behind rehabilitation using phytoremediation techniques is to enhance vegetation in areas normally not inhabited due to the high content of metals/metalloids which may not be conducive for plant growth [30]. Metallophytes have adapted to such conditions and their 
hyperaccumulation properties, in particular, could be the best option to use in mine rehabilitation. The use of hyperaccumulators to clean-up contaminated areas may take a very long period of time, but the reduction of toxicity in the soil is expected and therefore there is the possibility of other plants that are not metallophytes thriving and propagating. With the identification of hyperaccumulator ferns, particularly for $\mathrm{Cu}$ and As, experimental rehabilitation studies were performed in 2 selected sites, and these were Kias, Benguet and Suyoc North, Surigao. Kias is a $\mathrm{Cu}-\mathrm{Au}$ ore processing plant used by small-scale miners. Small ponds were constructed to accommodate the tailings/waste from the processing of ores. The $\mathrm{Cu}$ and As values of the tailings vary from 1990.0 to $6112.0 \mathrm{mg} \mathrm{kg}^{-1} \mathrm{Cu}$ and $63.1-130.0 \mathrm{mg} \mathrm{kg}^{-1}$ As. Suyoc North is an abandoned open pit $\mathrm{Cu}$ mine. The $\mathrm{Cu}$ and As values of the soil vary from 98.7 to $3390.0 \mathrm{mg} \mathrm{kg}^{-1} \mathrm{Cu}$ and $16.8-100.0 \mathrm{mg} \mathrm{kg}^{-1}$ As. In both of the selected sites, very minimal vegetation is observed.

In Kias, $P$. vittata and $P$. calomelanos were propagated in a nursery following the protocol forwarded by [31]. Upon maturity, they were transferred to the experimental plots within the tailings pond. The growth of the plants was monitored for about 2-3 months during which time soil samples were analyzed for $\mathrm{Cu}$ content. The $\mathrm{Cu}$ values ranged from 3829.69 to about $4165.33 \mathrm{mg} \mathrm{kg}^{-1}$. The ferns thrived very well accumulating $\mathrm{Cu}$ values at a range of about $43.0-294.0 \mathrm{mg} \mathrm{kg}^{-1}$ for $P$. vittata, and a range of $63.0-91.33 \mathrm{mg} \mathrm{kg}^{-1}$ for $P$. calomelanos. Building an ecosystem after 6 months promoted plant growth where other metallophytes apparently grew very well with the ferns. These plants were Alternanthera sessilis, Solanum nigrum and Chenopodium ambrosioides. Their growth extended to other parts of the pond, hence vegetation prospered. The Cu contents of the different metallophytes were $6598.0 \mathrm{mg} \mathrm{kg}^{-1}$ (A. sessilis), $2071.0 \mathrm{mg} \mathrm{kg}^{-1}$ (S. nigrum) and $1046.0 \mathrm{mg} \mathrm{kg}^{-1}$ (C. ambrosioides). The analyses of the different plants indicated that some have the potential capability of $\mathrm{Cu}$ accumulation and $A$. sessilis is of particular interest as it has a $\mathrm{Cu} B F$ value of 1.62. Understanding the efficiency of uptake of the plants may require further studies on the bioavailability of the metals/metalloids which are influenced by factors such as $\mathrm{pH}$, organic matter, and NPK content of the soil.

At Suyoc North, P. calomelanos was used for the experimental rehabilitation of the abandoned openpit $\mathrm{Cu}$ mine. $P$. calomelanos is an indigenous fern and naturally growing and abundant in the study site. After propagating P. calomelanos and cultivating it to maturity, it was transferred and planted at Suyoc North (Fig. 2). Immediate care was provided, e.g. in the form of watering and inputs of macronutrients. Sustaining the care process, however, was a challenge which resulted in an approximately $50 \%$ mortality rate. After 6 months, the soil and the ferns that survived and grew very well and were analyzed for $\mathrm{Cu}$ content. The original soil contained about $372 \mathrm{mg} \mathrm{kg}^{-1} \mathrm{Cu}$ and after the experimental rehabilitation the $\mathrm{Cu}$ content of the soil was reduced to $263.67 \mathrm{mg} \mathrm{kg}^{-1}$. The $\mathrm{Cu}$ content of the P. calomelanos was $689.67 \mathrm{mg} \mathrm{kg}^{-1}$ for the belowground components and about $112.67 \mathrm{mg} \mathrm{kg}^{-1} \mathrm{Cu}$ for the aboveground components. Much of the absorbed $\mathrm{Cu}$ from the soil was apparently stored in the root system of the plant with minimal uptake to the stem and leaves. Further field studies on the survival of cultivated, supposedly indigenous ferns in any rehabilitation project should be pursued. Sustained care for the growth of the ferns during the rehabilitation followed an initial care program and in the process identified problems leading to the relatively high mortality rate of the ferns. One of the problems encountered was the handling of the ferns from the nursery to the rehabilitation sites which apparently was stressful for the plants. High mortality was observed when the roots of the plants were agitated during transplanting and therefore they should be handled with care as this is critical to the survival of the plants. Another problem was the time of planting, which was not during the seasonal rainfall and thus the soils were relatively dry and this might have affected the bioavailability of nutrients and led to the eventual death of some plants. It is important that the care of the plants be sustained by regularly providing water, since high rates of transpiration are expected due to the direct exposure of the plants to sunlight. Similar problems were encountered elsewhere such as the phytoremediation of As contaminated soils in Florida [32], China [33] and Australia [34]. The field trials used $P$. vittata and yielded a positive result, indicating the feasibility of more large-scale environmental clean-up projects concerning As contaminated soils. However, a number of problems were encountered: 1) the availability of substantial number of mother plants, 2) uniformity in age, 3) high transportation costs and improper handling of the plants, and 4) high stress and mortality during transport and transplanting.

\subsection{Phytomining}

Electrowinning is a relatively old metallurgical/ chemical process of extracting metals from a solution. It uses an insoluble anode and cathode in an electrolyte cell (Fig. 3). With the use of electrical current and the reaction of metal ions, the win 


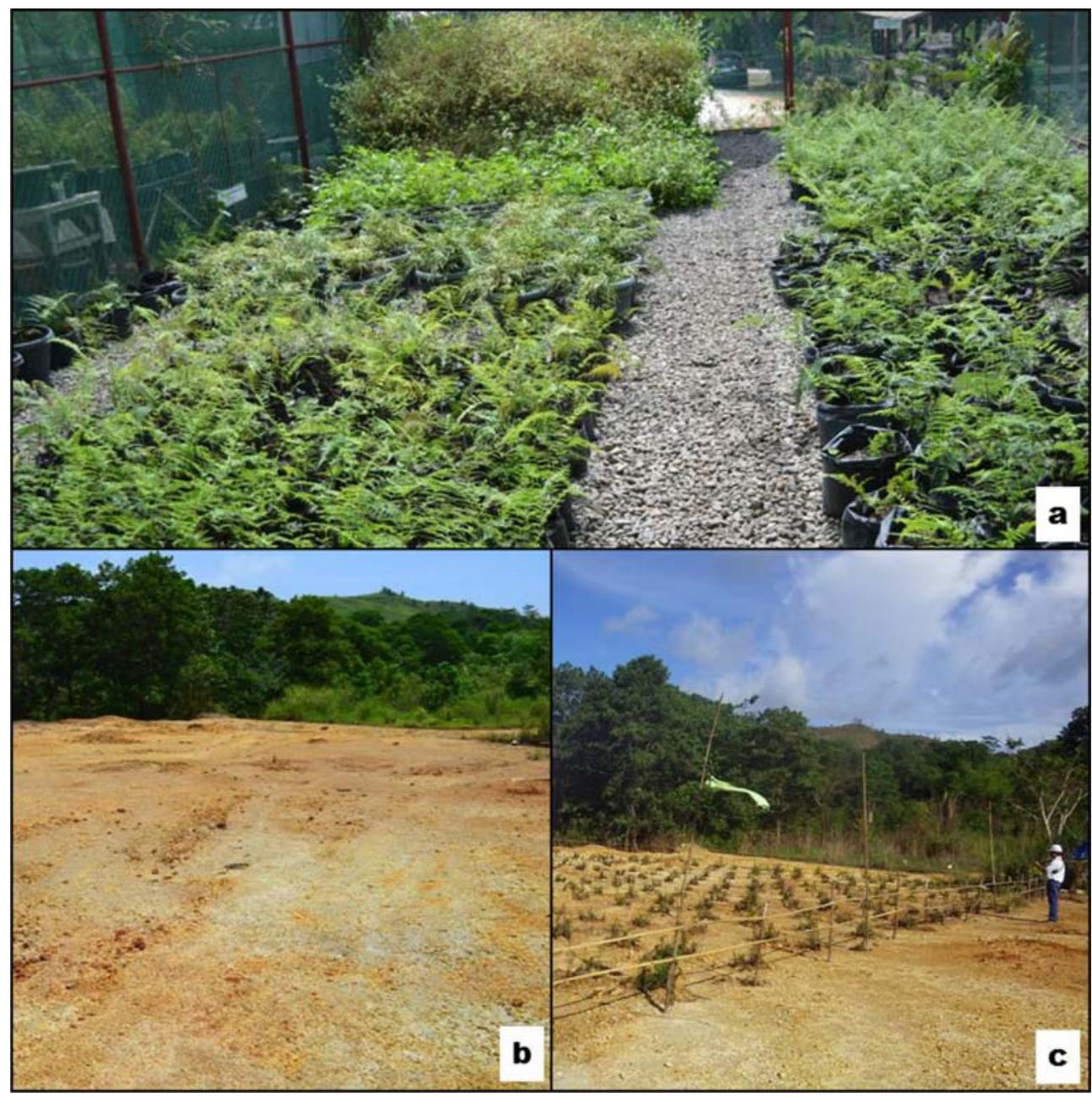

Fig. 2. Photographs of post-mining rehabilitation activities. a) nursery at Xavier University where most of the ferns were propagated, b) the experimental rehabilitation site at Suyoc North (Surigao) which was completely barren of vegetation, c) rehabilitation experiment using $P$. calomelanos at Suyoc North.

metals of high purity are deposited on the cathode [35]. This method is also used by mining companies for extracting valuable minerals from $\mathrm{Cu}-\mathrm{Au}$ ores. The use of electrowinning in bioremediation studies was initially performed by [36] in the removal of various metals from acid mine drainage. In the electrowinning experiments with the use of the nitric acid digestion method, the recovery of $\mathrm{Cu}$ from a solution during electrowinning was relatively high, ranging from 72 to $99 \%$, with most of the samples having $\mathrm{Cu}$ recovery of $>90 \%$ (Table $2 \mathrm{a}$ ). The $\mathrm{Cu}$ recovery using the aqua regia digestion method ranged from 42 to $96 \%$ with most of the samples having a recovery of $>80 \%$ (Table $2 b$ ). It appears that the nitric acid digestion method was more effective than aqua regia in recovering $\mathrm{Cu}$ from P. melanocaulon. Notable decreases in the $\mathrm{Cu}$ content of both solutions were observed. The recovery of $\mathrm{Cu}$ is already efficient at $30 \mathrm{~min}$ and at $1.5 \mathrm{~V}$. The results of the experiments also indicated that there were no significant differences in the recovery of $\mathrm{Cu}$ across different times (e.g. 30, 60 and $90 \mathrm{~min}$ ). In evaluating the effects of $\mathrm{pH}$, it was noted in both solutions that there was high $\mathrm{Cu}$ recovery with low $\mathrm{pH}$. It was also noted that there was an increase in the $\mathrm{pH}$ of the solution after electrowinning. The increase of the temperature of both solutions after electrowinning appears to be related to the increase of voltage which apparently increased $\mathrm{Cu}$ recovery. The increases in temperature are likely to put the metal ions into a more mobile state in the solution and thus increase the plating efficiency. The assessment of the overall efficiency of electrowinning shows that there is relatively high $\mathrm{Cu}$ recovery at low voltage as well as in a short period of time and this indicates the practical application of having an 


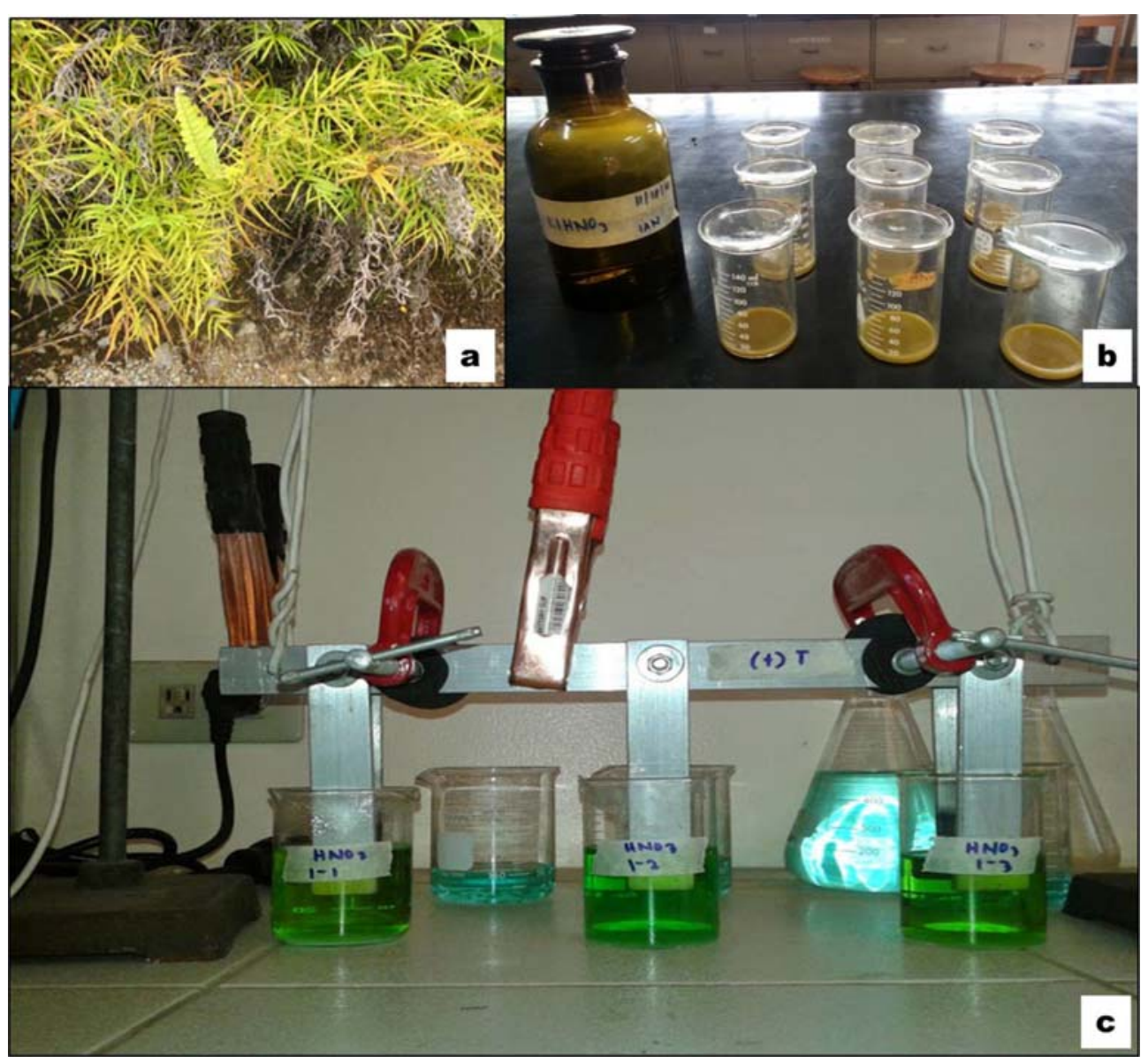

Fig. 3. Photographs on phytoextraction setups. a) P. melanocaulon was used as plant samples in the phytoextraction experiments, b) digested root components of $P$. melanocaulon in nitric acid. c) Electrowinning setup with 3 voltage variables considered. The greenish and bluish solutions are the results of tests using concentrated and diluted nitric acids.

electrowinning setup which leads to appreciable amounts of time and energy being saved in the recovery of $\mathrm{Cu}$ from hyperaccumulator plants. Due to the difficulty of using strong acids, such as nitric acid and aqua regia, the alternative of dry ashing the plant samples is recommended and after this there

Table $2 b$. Average concentrations ( $\mathrm{mg} \mathrm{kg}^{-1}$ ) of $\mathrm{Cu}$ in the roots of P.melanocaulon digested with aqua regia before and after electrowinning. Percentages of $\mathrm{Cu}$ recovery are provided at different times and voltages.

\begin{tabular}{|c|c|c|c|c|c|c|c|c|c|}
\hline \multirow[t]{2}{*}{ Voltage } & \multicolumn{3}{|l|}{$30 \mathrm{~min}$} & \multicolumn{3}{|l|}{$60 \mathrm{~min}$} & \multicolumn{3}{|l|}{$90 \mathrm{~min}$} \\
\hline & Before $\left(\mathrm{mg} \mathrm{kg}^{-1}\right)$ & After $\left(\mathrm{mg} \mathrm{kg}^{-1}\right)$ & $\%$ & Before $\left(\mathrm{mg} \mathrm{kg}^{-1}\right)$ & After $\left(\mathrm{mg} \mathrm{kg}^{-1}\right)$ & $\%$ & Before $\left(\mathrm{mg} \mathrm{kg}^{-1}\right)$ & After $\left(\mathrm{mg} \mathrm{kg}^{-1}\right)$ & $\%$ \\
\hline 1.5 & $8053 \pm 2073$ & $715 \pm 489$ & 91 & $8813 \pm 874$ & $667 \pm 402$ & 92 & $8610 \pm 452$ & $340 \pm 207$ & 96 \\
\hline 3 & $6899 \pm 832$ & $3979 \pm 3630$ & 42 & $7374 \pm 2773$ & $728 \pm 237$ & 90 & $4665 \pm 134$ & $571 \pm 564$ & 88 \\
\hline 6 & $5831 \pm 383$ & $689 \pm 20$ & 88 & $5735 \pm 146$ & $415 \pm 132$ & 93 & $5256 \pm 705$ & $658 \pm 462$ & 87 \\
\hline
\end{tabular}

Table $2 a$. Average concentrations $\left(\mathrm{mg} \mathrm{kg}^{-1}\right)$ of $\mathrm{Cu}$ in the roots of P.melanocaulon digested with nitric acid before and after electrowinning. Percentages of $\mathrm{Cu}$ recovery are provided at different times and voltages.

\begin{tabular}{|c|c|c|c|c|c|c|c|c|c|}
\hline \multirow[t]{2}{*}{ Voltage } & \multicolumn{3}{|l|}{$30 \mathrm{~min}$} & \multicolumn{3}{|l|}{$60 \mathrm{~min}$} & \multicolumn{3}{|l|}{$90 \mathrm{~min}$} \\
\hline & Before $\left(\mathrm{mg} \mathrm{kg}^{-1}\right)$ & After $\left(\mathrm{mg} \mathrm{kg}^{-1}\right)$ & $\%$ & Before $\left(\mathrm{mg} \mathrm{kg}^{-1}\right)$ & After $\left(\mathrm{mg} \mathrm{kg}^{-1}\right)$ & $\%$ & Before $\left(\mathrm{mg} \mathrm{kg}^{-1}\right)$ & After $\left(\mathrm{mg} \mathrm{kg}^{-1}\right)$ & $\%$ \\
\hline 1.5 & $7409 \pm 4013$ & $2082 \pm 930$ & 72 & $4519 \pm 1677$ & $151 \pm 25$ & 96 & $7756 \pm 923$ & $119 \pm 11$ & 98 \\
\hline 3 & $8291 \pm 3086$ & $114 \pm 29$ & 98 & $7675 \pm 548$ & $110 \pm 14$ & 98 & $7353 \pm 1654$ & $103 \pm 25$ & 98 \\
\hline 6 & $10337 \pm 3363$ & $178 \pm 22$ & 98 & $11820 \pm 3729$ & $139 \pm 29$ & 98 & $10923 \pm 2180$ & $86 \pm 94$ & 99 \\
\hline
\end{tabular}


is the possibility of using weaker acids in the digestion processes.

\section{Conclusions and recommendations}

Indigenous ferns thrived very well in areas poorly inhabited by other plant species due to the enrichment of metals/metalloid in the soil. The identified ferns in this study are classified either as excluders or as extractors depending on their naturally/adaptive uptake mechanisms. The identification took into consideration the concentrations of heavy metals in the soil as well as in the AG and BG components of the plant. The concentration values were used to determine the BF and TF ratios. Ferns that are classified as excluders commonly have BF values of $>1.00$ and for the extractors the TF values are commonly $>1.00$. $P$. vittata, $P$. calomelanos and $P$. melanocaulon have TF values of As are $>1.00$ with $P$. melanocaulon also exhibiting $\mathrm{BF}$ values for $\mathrm{Cu}$ of $>1.00$. With $\mathrm{BF}$ and TF values of $>1.00$, these ferns are the best candidates for post mining rehabilitation and phytomining. In mine rehabilitation, these ferns can partly reduce the $\mathrm{Cu}$ and As content of the soil, paving the way for other plants, which are normally not tolerant of the contaminated soil, to survive and thrive very well, increasing the vegetative potential of the area. These hyperaccumulator ferns can also be harvested as raw materials for $\mathrm{Cu}$ recovery using electrowinning processes. It is highly recommended that further studies be carried out on the simultaneous or sequential recovery of associated heavy metals of $\mathrm{Cu}$ using electrowinning. This would be significant in providing assurances that the solutions used in the recovery processes are not released into the environment as contaminated wastewater. It is also recommended that application research be performed on the rehabilitation process to increase the survival of the ferns and on other recovery processes to efficiently extract the heavy metals from the plants.

\section{Conflicts of interest}

None declared.

\section{Ethical statement}

The authors state that the research was conducted according to ethical standards.

\section{Funding body}

The Philippine Council for Industry Energy and Emerging Technology Research and Development (PCIEERD) - Department of Science and Technology (DOST), Philippines.

\section{Acknowledgments}

The authors would like to thank the Philippine Council for Industry, Energy and Emerging Technology Research and Development (PCIEERD)Department of Science and Technology (DOST) for providing financial support to the $\mathrm{Cu}$-As recovery project and to mining companies such as the Lepanto Consolidated Mining Company, Manila Mining Corporation, Philex Mining, Silangan Mining, Carmen Copper Corporation and small scale mining cooperatives, such as the Benguet Federation of Small Scale Miners Inc. (BFSSMI) and the Emerald Small Scale Miners Multi-purpose Cooperative (ESSMMC) for allowing access to the different mining sites and the gathering of plant and soil samples. Acknowledgement is also made to the collaborative work provided by Xavier University. Special gratitude is given to all of the students and faculty members of the Department of Environmental Science of the Ateneo de Manila University who have contributed to the success of the project. Our sincerest gratitude is extended to the reviewers of this paper whose comments and suggestions have greatly improved the content and presentation of data as well as the discussions and interpretations. To them we are most grateful.

\section{References}

[1] Baker A, Whiting S. In search of the Holy Grail - a further step in understanding metal hyperaccumulation. New Phytologist 2003;155(1):1-4.

[2] Anderson CWN, Brooks RR, Stewart RB, Robinson BH. The phytoremediation and phytomining of heavy metals. In: Proceedings PACRIM. 99; 1999. p. 127-35.

[3] Brooks RR, Robinson BH. The potential use of hyperaccumulators and other plants for phytomining. In: Brooks RR, editor. Plants that hyperaccumulate heavy metals. Oxon, UK: CAB International; 2004. p. 261-88.

[4] Marques AP, Rangel AO, Castro PM. Remediation of heavy metal contaminated soils: Phytoremediation as a potentially promising clean-up technology. Crit Rev Environ Sci Technol 2009;39.

[5] United States Environmental Protection Agency. Phytoremediation resource guide. 1999. p. 1-56.

[6] Claveria RJR, Fischer HH. Petrology of part of the Ulugan Bay peridotite in central Palawan, Philippines. J Geol Soc Philippines 1991;46(1-2):15-30.

[7] Yumul Jr GP, Dimalanta CB. Geology of the southern Zambales ophiolite complex (Philippines): Juxtaposed terranes of diversed origin. J Asian Earth Sciences 1997;15(4-5):413-21.

[8] Ogura Y, Murata K, Iwai M. Relation between chemical components and particle size distribution of ores in the profile of nickeliferous laterite deposits of the Rio Tuba mine, Philippines. Chem Geol 1987;60(1-4):259-71.

[9] Mitchel AHG, Balce GR. Geological reatures of some epithermal gold systems, Philippines. J Geochem Explor 1990; 35(1-3):241-96.

[10] Association of Official Analytical Chemists. Official methods of analysis of AOAC. Arlington, VA (USA). 1995. Archive.com, http://archive.org/stream/gov.law.aoac.methods.1. 1990/aoac.methods.1.1990_djvu.txt. [Accessed 15 June 2013]. 
[11] Wei CY, Chen TB. Arsenic accumulation by 2 brake ferns growing on an arsenic mine and their potential in phytoremediation. Chemosphere 2006;63:1048-53.

[12] Cui S, Zhou Q, Chao L. Potential hyperaccumulation of $\mathrm{Pb}$, $\mathrm{Zn}, \mathrm{Cu}$ and $\mathrm{Cd}$ in endurant plants distributed in an old smeltery, Northeast China. Environ Geol 2007;51(6):1043-8.

[13] Dahmani-Muller H, Van Oort F, Balabane M. Metal extraction by arabidopsis halleri grown on an unpolluted soil amend with various metal-bearing solids: A pot experiment. Environ Pollut 2000;114:77-84.

[14] Ondrus MG. Environmental chemistry: Experiments and demonstrations. 2nd ed. Winnepeg: Wuerz Publishing; 1996.

[15] Claveria RJR, Perez TR, Perez REC, Algo JLC, Robles PQ. The identification of indigenous $\mathrm{Cu}$ and asmetallophytes in the Lepanto $\mathrm{Cu}-\mathrm{Au}$ mine, Luzon, Philippines. Environ Monit Assess 2019;191:185.

[16] Dela Torre JB, Claveria RJR, Perez REC, Perez TR, Doronila AI. Copper uptake by PterismelanocaulonFée from a Copper-Gold mine in Surigao del Norte, Philippines. Int J Phytoremediation 2014;18(5):434-41.

[17] Redojevic M, Bashkin V. Practical environmental analysis. Milton Road, Cambridge: The Royal Society of Chemistry; 1999.

[18] Yao P. The removal of heavy metal pollution with electromagnetic techniques. Providence, Rhode Island: Brown University; 2010.

[19] Brown C. Recovery of metals from effluents by high efficiency air agitation electrowinning. Proc 73rd Tech Con Am Electroplaters Soc, Philadelphia, PA 1986.

[20] Kachenko AG, Singh B, Bhatia NP. Heavy metal tolerance in common fern species. Aust J Bot 2007;55(1):63-73.

[21] Patchura P, Ociepa-Kubicka A, Skowron-Grobowska B. Assessment of the availability of heavy metals to plants based on the translocation index and the bioaccumulation factor. J Desalination and Water Treat 2016;57(3):1469-77.

[22] Dahilan JKA, Dalagan JQ. Bioavailability and accumulation assessment of copper in Pityrogramma calomelanos. Philippine J Sci 2017;146:331-8 (September).

[23] Meharg AA. Variation in arsenic accumulation - hyperaccumulation in ferns and their allies. New Phytologist 2003; 157:31-5.
[24] Reichman SM. The responses of plants to metal toxicity: A review focusing on copper, manganese and zinc. 2002. p. 1-54. Occasional Paper No.14.

[25] Zheng Y, Dai X, Wang L, Xu W, He Z, Ma M. Arsenate reduces copper phytotoxicity in gametophytes of Pteris vittata. J Plant Physiol 2008;165(18):1906-16.

[26] Lasat MM. Phytoextraction of toxic metals: A review of biological mechanisms. J Environ Quality 2002;31:109-19.

[27] Gonzaga MIS, Santos JAG, Ma LQ. Arsenic phytoextraction and hyperaccumulation by fern species. Sci Agric 2006;63: 90-101.

[28] Zhao FJ, Dunham SJ, McGrath SP. Arsenic hyperaccumulation by different fern species. New Phytol 2003;156: 27-31.

[29] Claveria RJR, Perez TR, Apuan MJB, Apuan DA, Perez REC. Pteris melanocaulon fee is an ashyperaccumulator. Chemosphere 2019;236:124380.

[30] Tordoff GM, Baker AJM, Willis AJ. Current approaches to the revegetation and reclamation of metalliferous mine wastes. Chemosphere 2000;41:219-28.

[31] Apuan D, Apuan MJ, Perez TR, Claveria RJR, Perez RE, Doronila A, et al. Propagation protocol of Pteris vittata L using spores for phytoremediation. Int J Biosci 2016;8(6):14-21.

[32] Kertulis-Tartar GM, Ma LQ, Tu C, Chirenje T. Phytoremediation of an arsenic-contaminated site using Pteris vittato L: A two-year study. Int J Phytoremediation 2006;8(4):311-22.

[33] Xie QE, Yan XL, Liao XY, Li A. The arsenic hyperaccumulator fern PterisvittataL. Environ Sci Technol 2009; 43(22):8488-95.

[34] Niazi NK, Singh B, Van Zwieten L, Kachenko AG. Phytoremediation potential of Pityrogramma calomelanos var. austroamericana and Pteris vittata L. grown at a highly variable arsenic contaminated site. Int J Phytoremediation 2011;13: 912-32.

[35] Astley, D., Bawden, J., Scholes, I., Jacobi, J., Brooks, G. (1977).Electrowinning metals; U.S. Patent Number 4,039,403.United States Patent Trademark Office, USA.

[36] Ubaldini S, Abbruzzese C, Fornari P, Luptakova A, Prascakova M. Electrowinning and bioremediation processes for toxic metals removal from acid mine drainage. ActaMetallurgicaSlovaca 2006;12:405-10. 